\author{
Czesław Machelski \\ prof. dr hab. inż. \\ Politechnika Wrocławska \\ Wydział Budownictwa Lądowego i Wodnego \\ Katedra Mostów i Kolei \\ czeslaw.machelski@pwr.edu.pl
}

\title{
The vehicle impact on the corrugated steel shell in soil-steel structures
}

\begin{abstract}
The paper presents the results of soil-steel structures tests under road and rail vehicles loads, which change their position alongthe track. Quasi static loads are considered in both stepping and continuous measurement method (with minimum travel speed). The impact of dynamic loads from vehicles as a function of vehicle speed was analyzed. Heavy, lowspeed driving rides and as a separate group the passage of passenger trains in high speed journeys were consi-dered. In this cases numerical simulations are performed using com-plex models of soil-steel structures. The specificity (difference) of dynamic effects from dynamic loads of rolling stock on soil-steel structures in relation to classic steel bridges is specified in the paper. The presented results from tests shows the favorable interaction of the railway tracks and substructures with the corrugated steel shell in the backfi lling as in the railway embankments.
\end{abstract}

Keywords: Soil-steel structures; Impact of vehicle on the shell; Dynamic; Inves-tigation of the structures

\section{Construction of soil-steel facilities}

Soil-steel constructions are engineering structures that fulfill the role of bridge structures, as in Fig. 1, as well as overpasses, footbridges, culverts, tunnels, underground passages, farm crossings, passages for wild animals. A large group of these buildings performs the functions of municipal facilities, usually in the shape of closed (tubular) ducts. They are built in the form of a shell and the surrounding it especially compacted soil. They are designed in such a way as to ensure long-lasting, beneficial interaction between the main elements of the support system (in a classic construction), i.e. a coating (supported on a foundation) and a backfill with a surface [7]. 


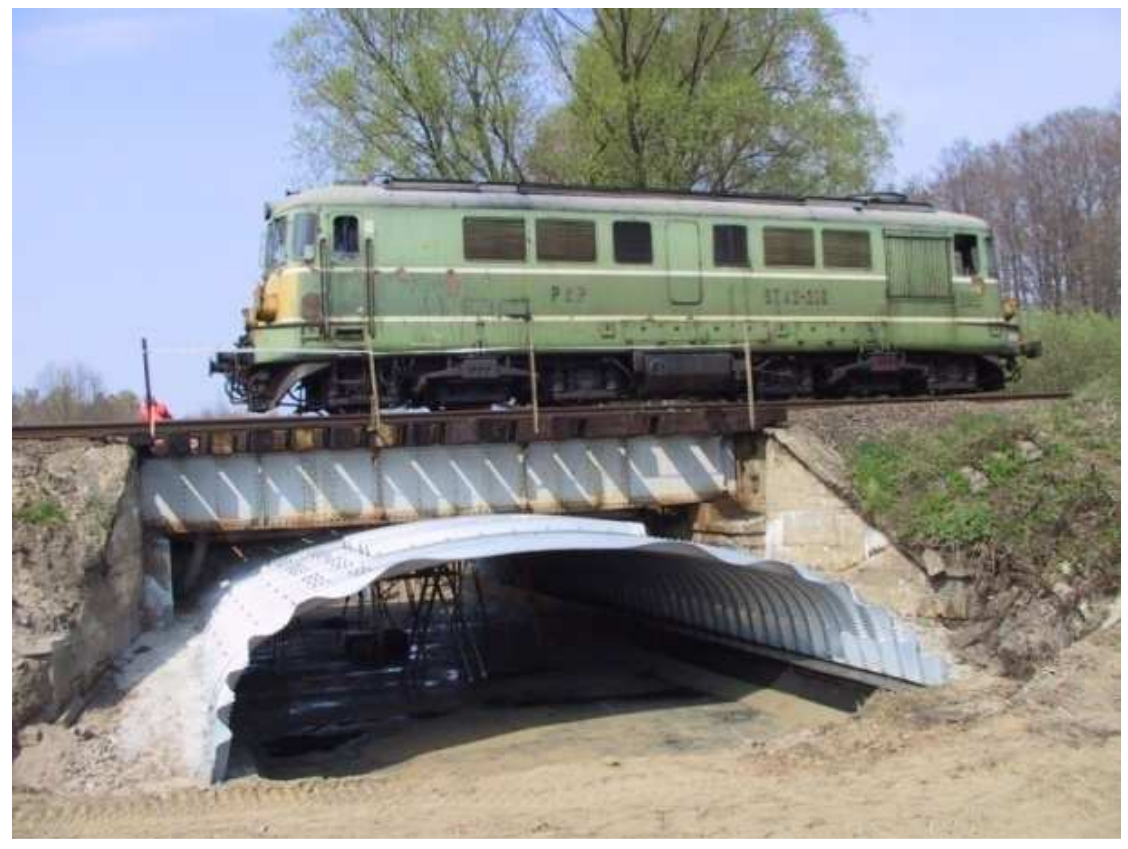

1. Reconstruction of a beam object to a soil-steel

The effect of co-operation with the soil is seen as apparently relieving the susceptible coating by creating a natural vault on the ground. The intensity of the soil's influence on the supporting structure depends on the stiffness of the coating in relation to the surrounding backfill $[8,11,12]$. In rigid construction, they have completely different roles. Due to the shape of the coatings of soil and shell structures, three types are distinguished: arches with closed and open sections, and box sections. This division results from differences in the course of deformation of the shells during the construction of the object [7]. Under variable loads, these differences disappear and all shells behave similarly $[4,12,13,18]$. Due to the material used, the coatings are made of flat and corrugated steel, steel, aluminum, and concrete. Deformations of these coatings are similar and their stiffness is important [12]. For this reason, soil-steel constructions are divided into two basic groups: rigid and susceptible. Detailed justification for the division of these objects is given in the paper [7].

\section{Changing location loads}

In communication objects of simple geometry (not located on curves), vehicles move along the longitudinal axis of the road over the perimeter of the structure, as in Figure 2. When the movements of the analyzed construction point are registered, a graph is generated, depending on the location of the highlighted vehicle axis (reference) coordinate xp. When the vehicle moves at low speed its dynamic impact is limited, it is usually assumed to be a quasi-static load changing its position $[6,11,13]$.

Figures 3 - 6 discuss the results of road tests of a ground-shell facility operated since 1962 in the USA (Washington district) with a width of $B=9 \mathrm{~m}$ [18]. The thickness of the road surface with the level was extremely small and amounted to $h_{\mathrm{c}}=0.406 \mathrm{~m}$. The cross-section of the shell is a half-circle shape. The characteristic geometric parameters of the coating are: span $L=5.59 \mathrm{~m}$; height $H=2.72 \mathrm{~m}$. The analyzed object was created from sheet metal with a low profile MP $152 \times 38 \times$. In these tests, a typical three-axle truck with a wheelbase of $a_{12}=$ $4.877 \mathrm{~m} a_{23}=1.372 \mathrm{~m}$ was used as the load. The loads on the axles of this car were similar and amounted : $P_{1}=80.77 \mathrm{kN} ; P_{2}=93.89 \mathrm{kN} ; P_{3}=93.22 \mathrm{kN}$. In the test program, the load changed its position along the road axis in a continuous and rolling way. 


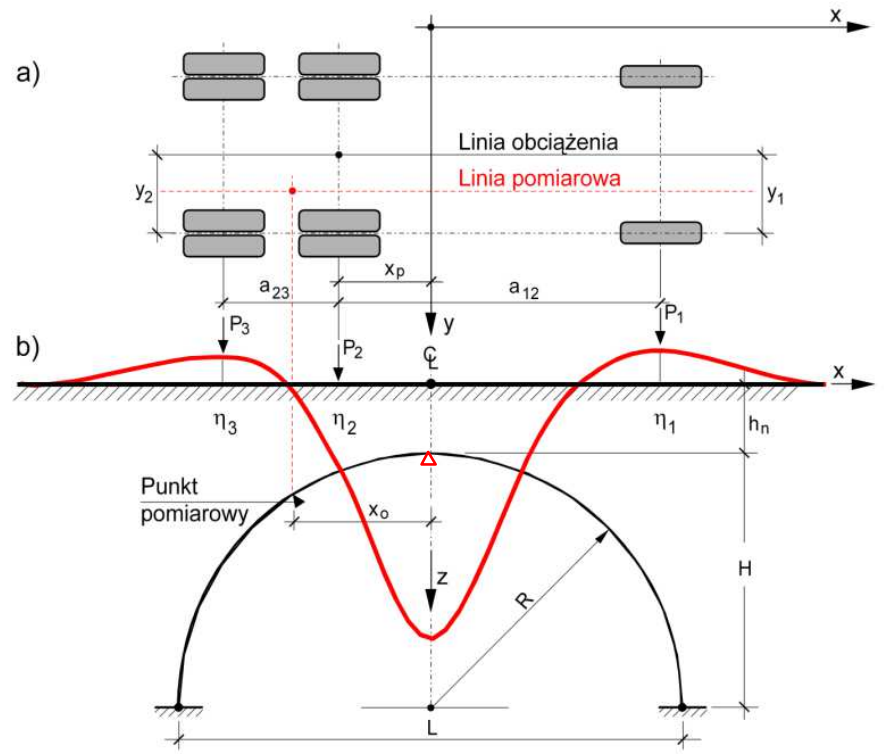

2. The car wheel layout and the impact line of the key deflection

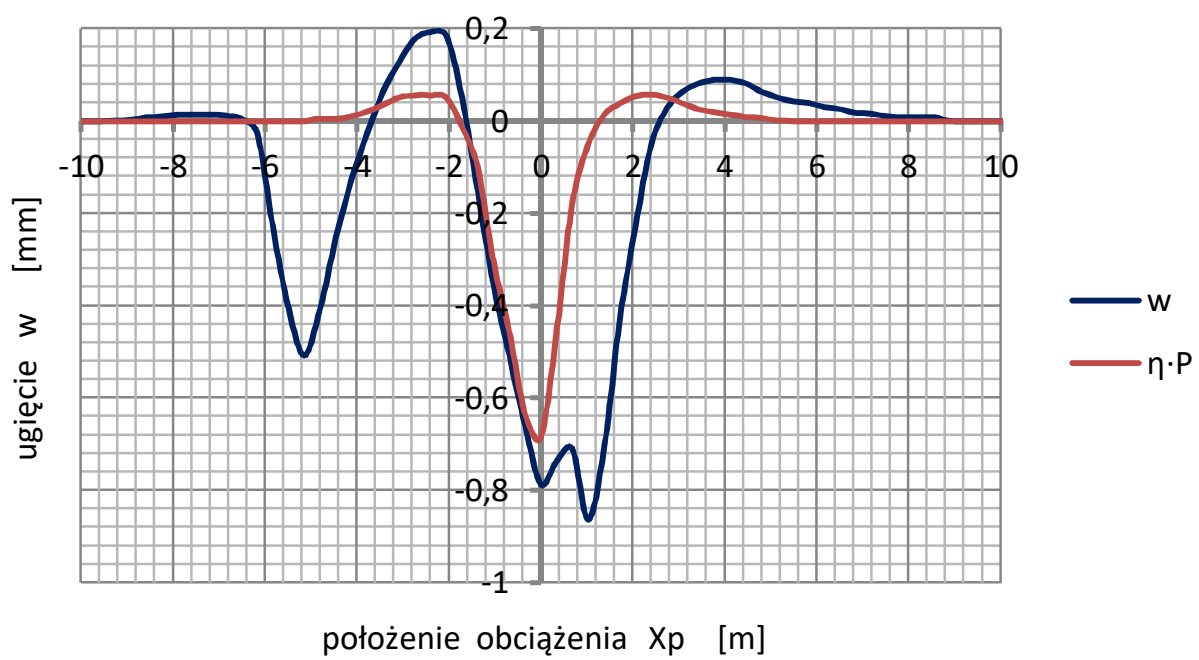

3. Changes in deflection and lines of influence of the deflection of the shell key 


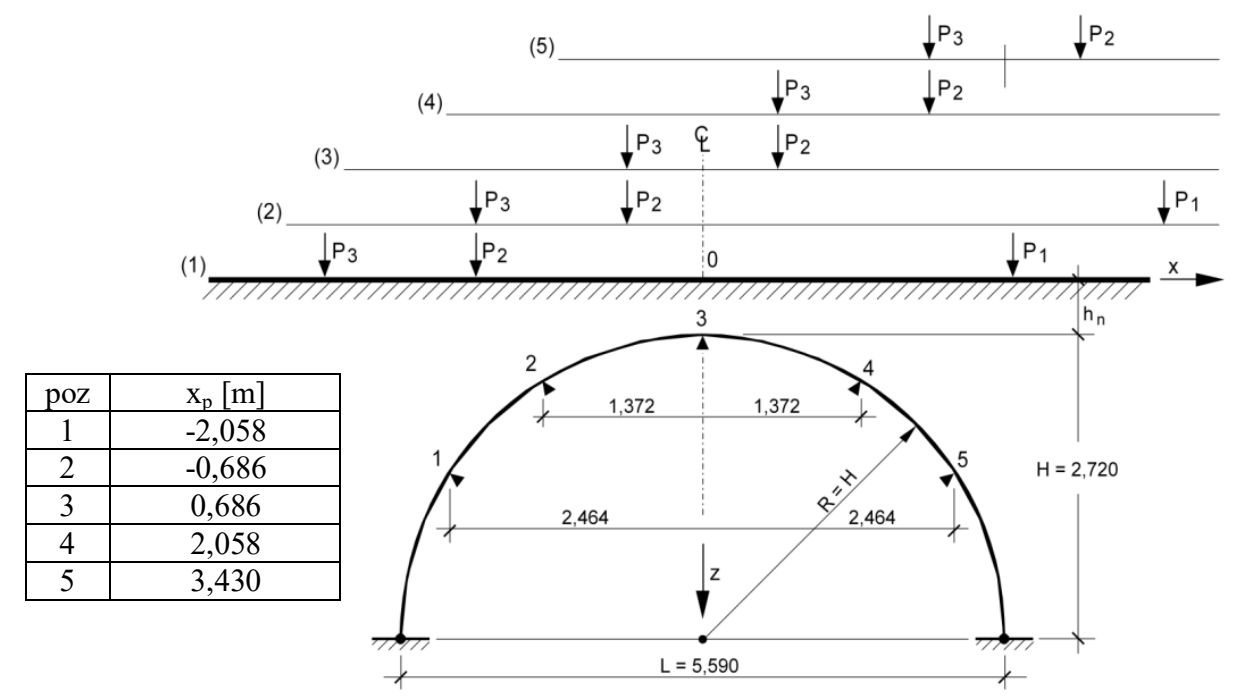

4. The position of the car in the implementation of the concept of the rolling load

a)

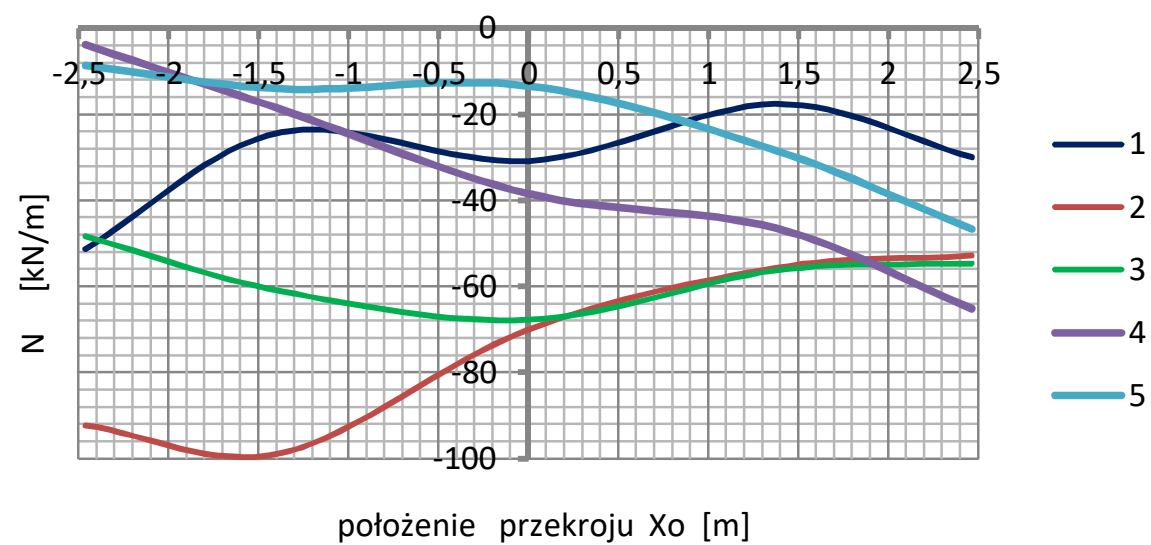

b)

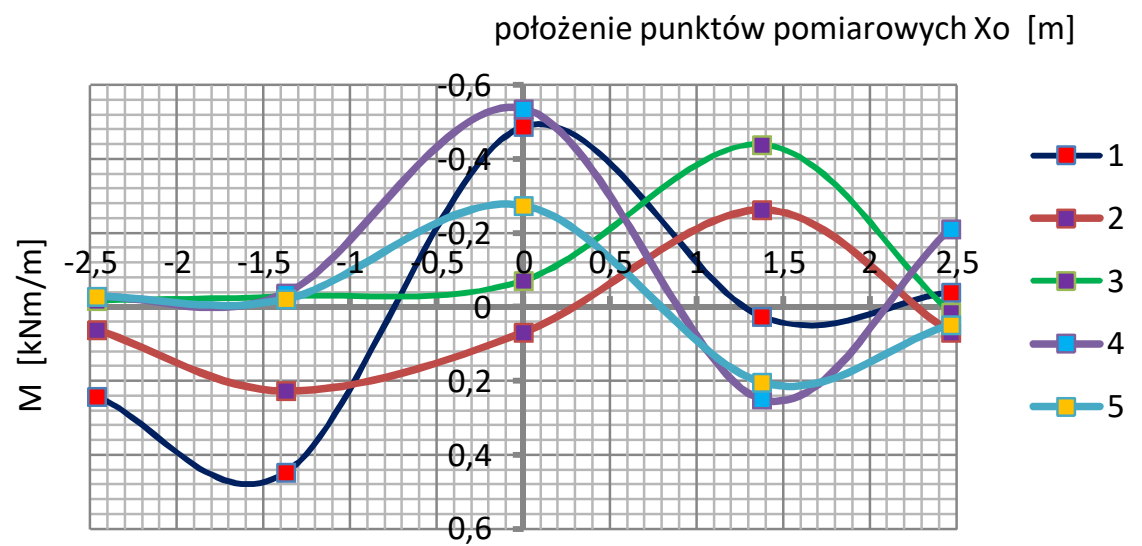

5. Distribution of axial forces and bending moments in the perimeter of the coating 
a)

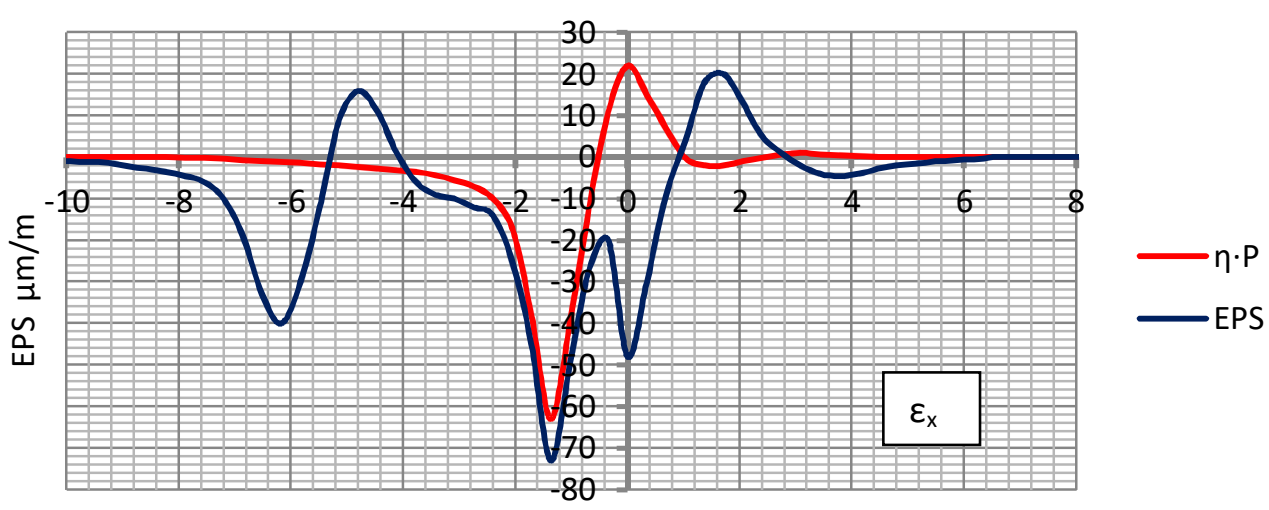

położenie obciążenia Xp $[\mathrm{m}]$

b)

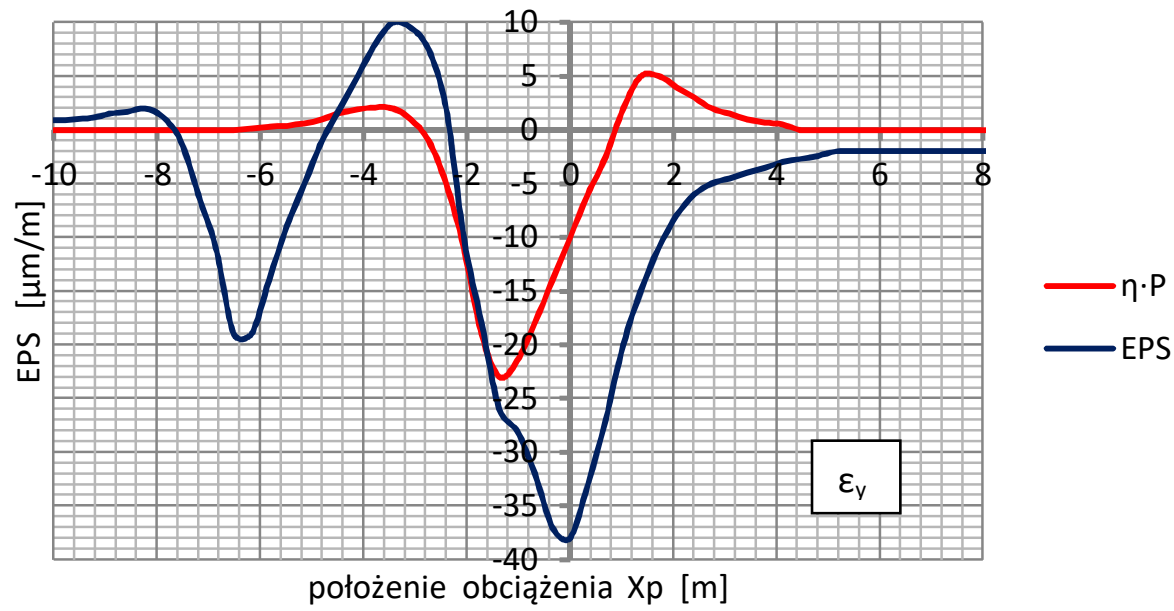

6. Variations in unit strain and impact lines $\varepsilon$ in point 2 of the shell

Figure 3 shows the result of the measurement of the shell key deflection $\mathrm{w}(\mathrm{x})$ during the passage of the car [18]. On the horizontal axis of the graph, the position of the center axle of the vehicle in relation to the shell key is given. When $x_{p}=0$, the center of the car is above the shell key. Visible in this figure, three extreme values of deflection are the result of loading successive wheels from the set. They arise in the case of a large wheelbase in relation to the $L$ -capacity. In the case of the car configuration, there may be a deflection $w=0$ despite the full car load. An important result of these measurements is the achievement of $w=0$ after the passage of the car usually remain residual deformations [2, 4, 6, 9, 11, 17].

Figure 4 presents the implementation of the concept of a rolling load - a car stopped while driving in five positions. In this particular case of the tested object and the axis system, there are similar geometrical relations between the spacing of the rear wheels of the car $a_{23}$ and the spread of $L$ as $a_{23} \approx L / 4=1.4 \mathrm{~m}$ and the system of measuring points $2,3,4$

In Figure 5 the values of internal forces in the analyzed points of the peripheral band of the shell are given as in Figure 4 calculated on the basis of tensometric measurements. The legend of the charts shows the location of the car changing its position in a rolling approach. In the test there are similar arrangements of the rear axles of the car in relation to the key shell, for example, diagrams 1 and 5 and 2 and 4 and symmetrical 3 . However, the impact of the front axle of the vehicle, or $P_{1}$, disturbs the symmetry of these internal forces. Axial forces $N$ (Figure 5a) are always one character (squeezing). In the case of bending moments, $M$ (Fig. 5b) 
between the forces $P_{2}$ and $P_{3}$ (rear axles of the vehicle) bending moments of the reverse sign appear in the shell than under the wheels. Due to the different position of forces in relation to the measurement points (as in Figure 4), the $M$ values given in the diagrams are not extreme and the graphs do not reflect the course of bending moments in the perimeter of the shell

In the object [18] analyzed earlier, tensometric measurements were also carried out, among others, at $x_{o}=-1.372 \mathrm{~m}$ as in Figure 4. Figure 6 shows the functions of unit deformation - in part $a$ graphs $\varepsilon_{\mathrm{x}}$ (in the circumferential direction) on the lower wave of the shell and in part $b$ $\varepsilon_{\mathrm{y}}$ (perpendicular to the circumferential direction) on the upper wave of the shell. The influence functions $\eta[1 / \mathrm{kN}]$ were multiplied by $P=P_{2}$ to represent them on a common graph with $\varepsilon$. Both functions $\varepsilon(\mathrm{x})$ and their influence lines are similar in shape as well as in value. Their specific difference is also visible. From the maximum ordinates $\varepsilon$, you can determine normal stresses as

$$
\sigma=E \cdot \varepsilon_{x}^{D}=0,205 \cdot 10^{6} \cdot\left(-74 \cdot 10^{-6}\right)=-15,2 \mathrm{MPa} .
$$

Stress mark "-" means compression. The deformation value is many times smaller than that created in the shell during construction [12].

From the functions $w(x)$, as in Fig. 3 and $\varepsilon(x)$, as in Fig. 6 and the effect lines $\eta(x)$ created on this basis, the lower efficiency of determining maximum values in the concept of the walking load is visible, as in the drawing 4. In the rolling approach, results are obtained by measuring points only at fixed load positions $x_{\mathrm{p}}$. Due to the multiple changes of the line effect of the analyzed values and with the complex geometry of the vehicle and different pressure on the wheels, extreme values may occur in unexpected load positions $[17,18]$.

\section{Lines of influence of displacements and internal forces}

From the continuous measurement of the deflection, the $w(\mathrm{x})$ diagram is created and hence the diffraction influence lines $\eta(x)$. Figure 3 shows both lines. To obtain the same units, the function $\eta(x)$ [mm / kN] was multiplied by $P=P_{2}[\mathrm{kN}]$. Two situations can be distinguished in the system of these two graphs:

- when only the first axis is above the impact line, then there is a dependence

$$
w(\mathrm{x})=P_{1} \cdot \eta_{1}\left(x+a_{12}\right)
$$

- when the second axis influences the deflection of the shell key, as in the pattern

$w(\mathrm{x})=P_{1} \cdot \eta_{1}\left(x+a_{12}\right)+P_{2} \cdot \eta_{2}(x)$

- in the general case, as in Figure 2, there is a dependency

$w(\mathrm{x})=P_{1} \cdot \eta_{1}\left(x+a_{12}\right)+P_{2} \cdot \eta_{2}(x)+P_{3} \cdot \eta_{3}\left(x-a_{23}\right)$

(3)

Using the equation (1), the first part of the graph $\eta\left(x+a_{12}\right)$ is determined. When there is an active interaction of the second axis of the $P_{2}$ vehicle, the ordinates of the $\eta_{2}=\eta(x)$ graph are already known and the determined range of the $\eta\left(x+a_{12}\right)$ graph under the force $P_{1}$ using the equation (2). The case included in equation (3) is general because all three axes of the vehicle affect the deflection of the shell key. In this case, the ordinates of the $\eta_{2}=\eta\left(x+a_{12}\right)$ and $\eta_{3}=$ $\eta(x)$ are known and the component $\eta(x)$ is determined from the force $P_{1}$, as in figure 2 . When the form of the influence function $\eta(x)$ is determined the general dependence is used

$$
w(x)=\sum_{i=1}^{3} P_{i} \cdot \eta_{i}\left(x_{i}\right)
$$

where: $x=x_{\mathrm{p}}, x_{1}=a_{12}-x_{\mathrm{p}} \mathrm{i} x_{2}=x_{\mathrm{p}}$ oraz $x_{3}=-a_{23}-x_{\mathrm{p}}$. 
From the values of the ordinates of the impact line $\eta(x)$, the active vehicle interaction area is visible - usually similar to $2 L$. The graph $w(x)$ presented in Figure 3 is the result of measurements carried out on the object and at the same time checking the correctness of the function $\eta(x)$ generated on the basis of the object's research. The advantage of the impact function $\eta(x)$ is to take into account all construction elements together with equipment cooperation (e.g. surface).

The same research methodology was used for vehicles with a greater number of axles - as in rolling stock. The examined railway object is shown in Figure 7. The coating of the soilsteel structure is made of SuperCor sheet with a wave SC SC $380 \times 140 \times 7$, with a sectional overlay (shell coats moved by one field) made of SC $380 \times 140 \times 5.5$ sheet. The geometry of the SC-35B perimeter band is designated by the manufacturer as a box. The characteristic dimensions of the coating are: span $L=7.945 \mathrm{~m}$, height $H=2.37 \mathrm{~m}$, upper radius of curvature $R=$ $8.82 \mathrm{~m}$. Coating widths are as follows: upper $B_{g}=13.8 \mathrm{~m}$ and lower $B_{d}=21.36 \mathrm{~m}$. The object is characterized by very low construction height $h_{k}=1.20 \mathrm{~m}$, which at the total thickness of the 60E1 railway surface on the ballast and prestressed concrete sleepers gives a $0.95 \mathrm{~m}$ thick layer.

The object load was a six-axis locomotive type ST44 with a wheelbase: $2 \cdot 2.10+4.20+2$. $2.10 \mathrm{~m}$ and loads on axles $P=192.9 \mathrm{kN}$. In the study of the object, the load changing method was applied in a quasi-static manner. It consisted in passing the locomotive in successive settings with a fixed step, in this case, every two primers, that is, approximately every $1.3 \mathrm{~m}$. In these positions, the sag of the shell key was automatically registered (computerized).

On the basis of the obtained results, a graph was created in $w(\mathrm{x})$ given in Figure 8 . The ordinates are referred to the value of $x_{\mathrm{p}}$, which is the distance of the central force in the locomotive from the shell key. When $x_{\mathrm{p}}=0$, the central force in the locomotive is above the key. Subsequent locomotive travels were carried out continuously at low speeds so that dynamic effects would not occur. From these measurements, similar diagrams were obtained in (x)

From the shape of the graph $\mathrm{w}(\mathrm{x})$ you can see the share of three forces $\mathrm{P}$ in the locomotive's trolley and another invasion over the measuring point of the shell. The distance between the vertices of the graph is consistent with the spacing of the locomotive bogies, i.e.

$d=2 \cdot 2.1+4.4=8.6 \mathrm{~m}$

On the basis of the deflection curve in $w(\mathrm{x})$ the diffraction influence lines $\eta(x)$ were created on the same principles as in the case of the load analyzed in Figure 2. The accuracy test $\eta$ (x) is the deflection line $w(\mathrm{x})$ formed on this basis with the forces in considered points $x_{\mathrm{i}}$ is

$$
w(x)=P \sum_{i=1}^{6} \eta\left(x_{i}\right)
$$

when

$$
x_{i}=\{x+2,1 ; x ; x-2,1 ; x-6,5 ; x-8,6 ; x-10,7\} .
$$

\section{Stiffness of the bridge object}

In the case of bridge structures subjected to mobile loads, stiffness $k$ is used as a technical parameter both in ground and coating objects as well as in classical bridges $[6,9]$. The $k$ values depend on the construction of the structure, material and especially on the span of the object. For this purpose, a deflection line created during the passage of a vehicle, e.g. a railway, is determined, and on this basis, the function of the influence of deflection, as in the diagrams given in the work. In works [6,9], the definition of stiffness of a bridge object is proposed as 
a proportion of the value of the concentrated force $P$ to the displacement induced by it, as in the formula

$$
k=\frac{P}{w} \quad[\mathrm{kN} / \mathrm{mm}] .
$$

In the case under consideration, a linear structure model is assumed, hence proportionality to $P$. The $P$ force is therefore arbitrary (it does not have to be the maximum value for a structure element), so $k$ does not depend on the intensity of the load. The minimum $k$ value obtained for a given structure is of significant importance here. In the case of bridge constructions, therefore, the position of force $P$ on the roadway is sought, at which the maximum displacement value $\mathrm{w}$ will occur. In this approach, the function of the impact of deflection $\eta(x)$ discussed earlier is used.

When the change of force $P$ takes place along a straight line, as in the case of a railway bridge, the problem is reduced to the form shown in Figures 2, 3, 8. By the definition of the impact line $\eta$ the displacement is calculated from the dependence

$w=P \eta$

where $\eta$ is the maximum elevation of the impact line. After substitution (8) to (8) is obtained

$k=\frac{1}{\eta} \quad[\mathrm{kN} / \mathrm{mm}]$.

Therefore, stiffness $\mathrm{k}$ is the inverse of the maximum ordinate of the impact line of deflection $\eta$ [10]. Thus, $\eta$ is also an indicator, however, $\eta$ takes into account the shell support scheme, its geometry, and surface. The $k$ values are useful for other types of bridges [6].

The following maximum values were obtained in the previously analyzed object examples:

- road object $\eta \cdot P=0.686 \mathrm{~mm}$ (figure 3), after considering force $P=93.89 \mathrm{kN}$ is obtained

$k=\frac{93.89}{0,686}=137 \quad[\mathrm{kN} / \mathrm{mm}]$

- rail object $\eta \cdot P=1.94 \mathrm{~mm}$ (figure 8), after considering force $P=192.9 \mathrm{kN}$ is obtained

$k=\frac{192.9}{1.94}=100 \quad[\mathrm{kN} / \mathrm{mm}]$

The stiffnesses calculated above are general measures and are used to determine bridges with different diagrams (beam, frame, arched, suspended, etc.). The values of $\mathrm{k}$ depend on the span $L$ (in the small bridges they are the largest, in the order of $k=300 \mathrm{kN} / \mathrm{mm}$ ). They also depend on the type of construction - the smallest values are found in footbridges even $k=15$ $\mathrm{kN} / \mathrm{mm}$.

\section{Dynamic effects}

The study of the effects of dynamic rail journeys distinguishes the operating speeds of heavy rail (freight) and lighter passenger trains. Separate analyses are carried out for rail vehicles adapted for high speeds $[1,3,5,14,15]$. Due to the scope of analyses carried out in the work on the largest impacts of vehicles, the focus was on locomotives used in acceptance tests, as shown in Figure 7. 


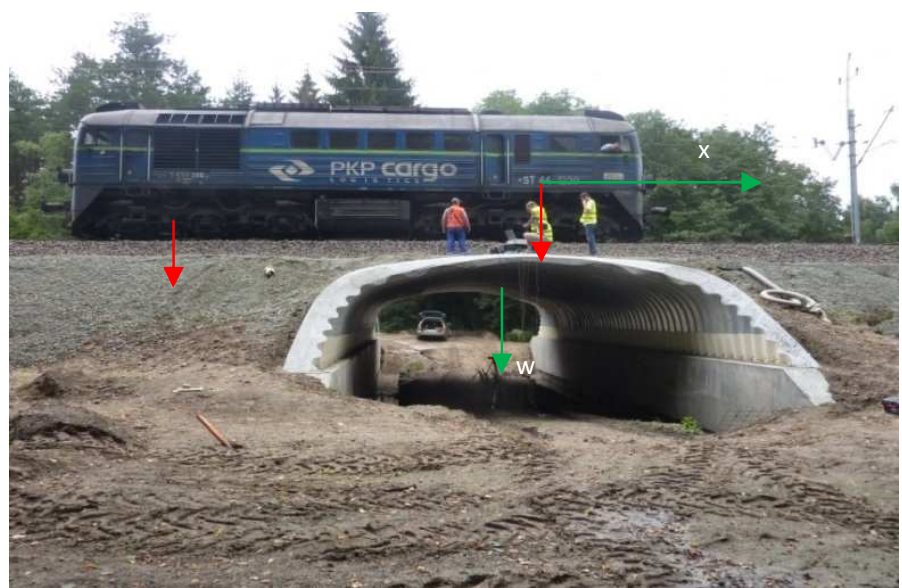

7. Location of the locomotive during loading

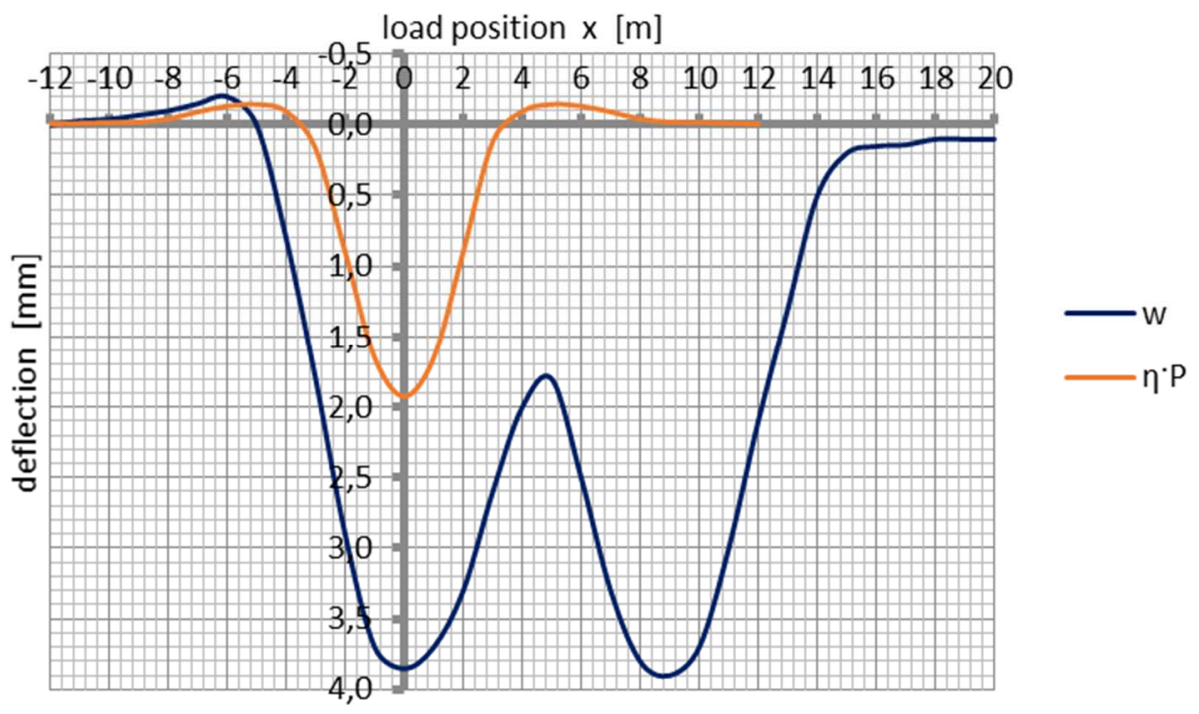

8. Deflection change and impact line of the key deflection

An example of the analysis considered at work is a typical railway object [17] with a boxshaped structure, soil-steel corrugated sheet SuperCor with SC $380 \times 140 \times 7$ wave. In such coatings, pads in the middle and corner sections are often used. The geometry of the SC-48B perimeter band with the characteristic dimensions of the shell: span $L=11.04 \mathrm{~m}$, height $H=$ $2.37 \mathrm{~m}$, the upper radius of curvature $R=8.82 \mathrm{~m}$. The object is characterized by a small height of the naval $h_{n}=0.85 \mathrm{~m}$.

The receiving load was a six-axle locomotive type $\mathrm{S} 1000$ with a wheelbase: $2 \cdot 2.00+4.66$ $+2 \cdot 2.00 \mathrm{~m}$ and a load on the $P$-axle $=193.7 \mathrm{kN}$. In the study of the object, the load changing method was used in a stepwise manner. It consisted of passing the locomotive in subsequent settings with a constant step. In these positions, the deflection of the shell key was registered automatically (computer). The basic research concerned the dynamic features of the object. In this case, continuous journeys were carried out at speeds of around $5,30,50,60 \mathrm{~km} / \mathrm{h}$. They allowed determining the dynamic coefficient (dynamic allowance) obtained from the measurement of the deflection of the shell key. These results are summarized in Figure 9. 


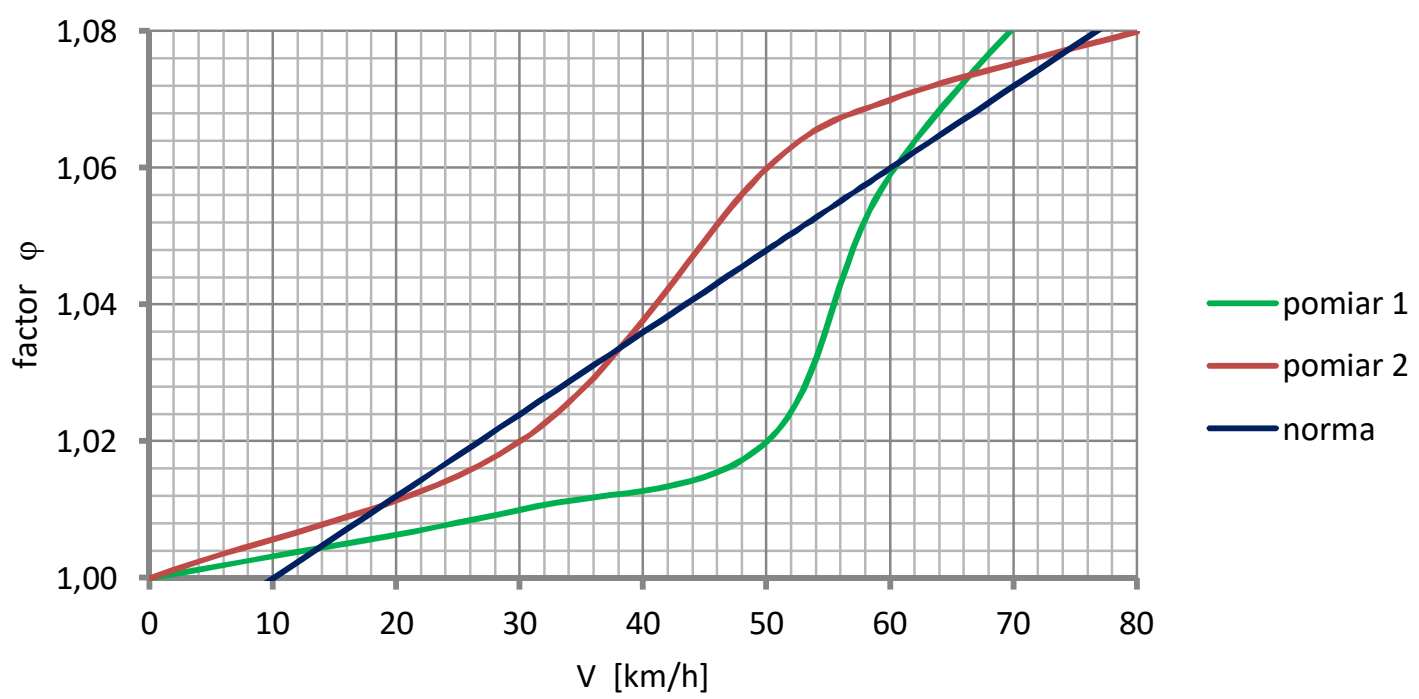

9. The values of the dynamic coefficient determined from the research

The measurements of the object result in small values of the dynamic coefficient $\varphi$. In the case of a classical bridge with a beam scheme, its value is much higher because of the analyzed value $L$, calculated from the standard formula equals

$\varphi=\frac{1,44}{\sqrt{L}-0,2}+0,82=1,281$.

In the case of bridges with a thickness layer $h_{\mathrm{n}}=0,85 \mathrm{~m}$ (as in the object), the value calculated from (11) is reduced as in the formula

$\varphi_{h}=1+2\left(1-h_{n}\right)(\varphi-1)=\frac{7+3 \varphi}{10}=1,084$.

The impact of vehicle speed is determined by dependence

$\varphi_{v}=1+\left(\varphi_{h}-1\right) \frac{V-10}{70}=1+\frac{3(V-10)}{2500}$,

when $V[\mathrm{~km} / \mathrm{h}]$. Based on formula (13), a graph was created as shown in Figure 9. It is consistent with the results of measurements on the object [17].

From the examples of studies given in many works, the influence of dynamic freight transports passing through soil and coating facilities is small. A separate problem is the behavior of these objects in the case of railway vehicles moving at high speeds $[1,3,5,15]$. In the case of soil-steel facilities, the problem of a passage of passenger trains adapted to high speeds (V> $160 \mathrm{~km} / \mathrm{h}$ ) concerns mainly the behavior of the ground center in such a construction. This is due to the larger axle spacing in railway vehicles and their smaller number involved in the impact on the shell [13]. Therefore, the effectiveness of the interaction of two axles of a vehicle with a much larger distance between the three axes of a heavy locomotive is smaller even with a much higher value of the dynamic coefficient. The passage through an object with a span $L=10 \mathrm{~m}$ at a speed of $180 \mathrm{~km} / \mathrm{h}$ is only $1 / 4$ second (when the length of the impact line is taken as $2 L$ ).

\section{Summary}

A special feature of soil-steel facilities is the lack of elements found in classic bridges: bearings, dilatation, bridgeheads. Due to the laying of ground backfill on the coating, the surface and foundation of the roadway in road and rail facilities have the same base as in the en- 
tire communication route (on embankments). Therefore, there is no reason to use additional elements in these objects to improve the flow of motion occurring in classic bridges (e.g. transition plates). The results of tests on the impact of vehicles on soil-steel objects show a significant reduction of dynamic effects. This is due to the high stiffness of the corrugated sheet immersed in the ground medium and the high inertia of the object, including the mass of the backfill constituting the structure.

\section{Source materials}

[1] Aktualne zagadnienia budownictwa komunikacyjnego (praca zbiorowa) Seria Monografie Zakładu Mechaniki Teoretycznej i Mechaniki Nawierzchni Komunikacyjnych, Warszawa 2015.

[2] Andersson A., Karoumi R.: A soil-steel bridge under high-speed railways. Archives of Institute of Civil Engineering 23/2017 p. 45-52.

[3] Asp O., Laaksonen A.: Instrumentation and FE-analysis of a large span culvert built under a railway. Structural Engineering International, Vol. 26 No. 4/2016 pp. 357-364.

[4] BayogluFlener E., Karoumi R.: Evaluation of the dynamic response of a soil-steel composite railway bridge. Archives of Institute of Civil Engineering, 12, 2012, 55-64.

[5] Klasztorny M.: Dynamika mostów belkowych obciążonych pociągami szybkobieżnymi. Wydawnictwa naukowo Techniczne, Warszawa 2005.

[6] Machelski C.: Ruchome obciążenia obiektów mostowych. Dolnośląskie Wydawnictwo Edukacyjne, Wrocław 2015.

[7] Machelski C.: Klasyfikacja obiektów gruntowo-powłokwych z uwagi na zmiany deformacji powłoki podczas budowy. Przegląd Komunikacyjny 9/2016 s. 5-10.

[8] Machelski C.: Szacowanie oddziaływania zasypki na powłokę obiektów gruntowopowłokwych na podstawie deformacji powłoki. Przegląd Komunikacyjny 11/2016, s. 31-36.

[9] Machelski C.: Stiffness of railway soil-steel structures. Studia Geotechnika et Mechanica. No. 4/2015 p. 29-36.

[10] Machelski C.: Kinematic method for the determination of influence function of internal forces in the steel shell of soil-steel Bridges. Studia Geotechnika et Mechanica. No. 3/2010 pp. 27- 40 .

[11] Machelski C., Janusz L.: Application of Results of Test in Developing 2D Model for Soil-Steel Railway Bridges. Journal of Transportation Research Board, Vol. 2656:53-6, January 2017.

[12] Machelski C., Janusz L., Czerepak A.: Estimation of Stress level in the Corrugated SoilSteel Structure Based on Deformations in the Crown. Journal of Traffic and Transportation Engineering 4(2016) p. 186-193.

[13] Machelski C., Mumot M.: Corrugated shell displacements during the passage of a vehicle along a soil-steel structure. Studia Geotechnika et Mechanica. No. 4/2016 p. 29-36.

[14] Madaj A., Surzbecher K., Porębski R., Janusz L.: Testing of Multiplate type structure under dynamic railway loads. Archives of Institute of Civil Engineering, 12, 2012, 185 195.

[15] Mellak P., Anderson A., Pettersson L., Karomi R., Dynamic behaviour of short span soil-steel composite bridge for high-speed raylways-field measurements and FEanalysis, Engineering Structures, Vol. 69, 15 June 2014, pp. 49-61.

[16] Surowiecki A., Machelski C., Saska P.: Numerical modeling of engineering soil shell structure. Journal of Science of the Military Academy of Land Force. Vol. 48 No 4(182) 2016 pp. 160-169. 
[17] Szcześniak W., Hypki M., Skulski B., Śledziewski K.: Badanie statyczne i dynamiczne mostu kolejowego o konstrukcji gruntowo-powłokowej. Logistyka 6/2014 s. 1025210268.

[18] White K., Sargand S., Masada T.: Evaluation of load rating procedure for metal culverts under shallow oil covers. Archives of Institute of Civil Engineering 23/2017 p. 311-323. 